\title{
Estimation Level of Leptin and Resistin in Sera Patients with Type Two Diabetes among Iraqi Peoples
}

\author{
Alaa Sami Husain ${ }^{1}$, Ali Yakub Majid ${ }^{2}$, Ahmad Sa,adi Hassan ${ }^{3}$ \\ ${ }^{1}$ B.Sc. Medical Laboratory Science Technology, Baghdad/National Blood Transfusion Center/Medical \\ City,Baghdad, Iraq, ${ }^{2}$ Ph.D. Biochemistry, Poisoning Consultation Center/Specialized Surgeries Hospital, \\ MedicalCity, Baghdad, Iraq, ${ }^{3}$ Ph.D. Chemistry, Medical Lab Technique, College of Health and Medical Technical, \\ Middle Technical University, Baghdad, Iraq
}

\begin{abstract}
Leptin it is a protein hormone containing 167 amino acids, firstly discovered in 1994 by Jeffrey M. Friedman, It is secreted by adipocytes and has been found to regulate food intakes through central neuroendocrine mechanisms. Resistin has been found to be generated and released via adipose tissue to serve endocrine functions which are likely to be associated with insulin resistance.
\end{abstract}

Aim: The aim of this study determination of leptin and resistin hormone level in serum of male and female with type 2 diabetic patients and healthy control in Iraq.

Subject and Method: This respective study carried out at three main medical facilities in Baghdad; National Center For Teaching Laboratories, Poisoning Consultation Center/Specialized Surgeries Hospital and the National Blood Transfusion center in Medical City,Iraq during the period from November 2019 to February 2020. It was included 100 participants; divided into 2 groups(50 patient with type 2 diabetes and 50 healthy control).

Results: The result of serum leptin showed that there was highly significant difference when comparing the mean of total serum leptin of patient group with that of the control group. While the mean of total circulating resistin in T2DM patient and healthy with no significant difference between the two groups.

Conclusion: Increased serum leptin level in type 2 diabetes patient than healthy control and no significant difference in serum resistin level when compared between diabetics and control

Keywords: Type Two diabetes, Leptin, Resistin.

\section{Introduction}

Diabetes is a complex, chronic disorder requiring continuous medical care ${ }^{1}$. It is a serious, long-lasting or chronic disorder that occurs when there are raised levels of glucose in a person's blood because their body cannot produce any or enough insulin, or cannot effectively use the insulin it produces. Insulin is an essential hormone produced by the beta cells in the islets of Langerhans in the pancreas. It allows glucose from the bloodstream to enter the body's cells where that glucose is converted into energy. The main function of this hormone is to lower the level of glucose in the blood by promoting the uptake of glucose by the adipose tissue and skeletal muscle, known as glycogenesis ${ }^{2}$. Ultimately to the homoeostasis of glucose which leads to complications like retinopathy, atherosclerosis, cardiovascular diseases, nephropathy and peripheral neuropathy. Type II diabetes usually affects people aged over 40 years. ${ }^{3}$ This metabolic disorder is characterized by target tissue resistance to insulin, It is epidemic in industrialized societies, and is strongly associated with obesity, Thus obesity is generally considered to be a strong risk factor for the later development of T2DM, and at times, they frequently occur together. Statistics show that $60 \%$ $90 \%$ of all patients with T2DM are or have been obese ${ }^{4}$ Leptin originates from of the Greek root leptos, meaning 
'thin'5. Leptinis predominantly derived from white adipose tissue and released as a 16 kilo Dalton [kDa] Non-glycosylated protein with LEP encoding gene, also referred LEP gene in human. Leptin binds to its receptor (LEPR) expressed in the central nervous system and peripheral tissues and performs its biological acts ${ }^{5,6}$. Generally, hyperleptinemia has been linked with T2DM, insulin resistance and complications of the vascular diabetes. Antidiabetic medicine can reduce leptin levels including sitagliptin, metformin, pioglitazone and liraglutide ${ }^{7}$. Resistin is a putative adipocytederived signaling of polypeptides hormone(ADSF) the Molecular weightis $12.5 \mathrm{kDa}$, with a length of 108 amino acids That is generated and released into the bloodstream from white adipose tissue, primarily by macrophages in human Resistin functions as the pathogenic factor which results in insulin resistance by antagonizing the action of insulin, thus raising gluconeogenesis and impairing the absorption of hepatic glucose $\mathrm{e}^{9-11}$.

\section{Subjects and Method}

This respective study was carried out at three main medical facilities in Baghdad; National Center For Teaching Laboratories, Poisoning Consultation Center/ Specialized Surgeries Hospital and the National Blood Transfusion center in Medical City,Iraq during the period from November 2019 to February 2020. It included 100 participants; divided into 2 groups(50 patient with type 2 diabetes and 50 healthy control) and 2 subgroups. The type 2 diabetic patient group were subdivided into(25 male, 25 female) with age (30-65) and healthy control group subgroup ( 25 male, 25 female) with age (29_65).All the information about each individual in the above groups including data about their age, height, weight, cigarette smoking, family history, duration of disease, habit and medication were collected by filling a questionnaire case sheet for each patient. Statistical Analysis: Data was conducted by using SPSS program (Statistical Package For Social Science) version 24.

\section{Method}

Leptin and resistin was estimated by using ELISA (Enzyme linked immunosorbent assay) Kit from SHANGHAI YEHUA Biological Technology, HbA1c was estimated for each type 2 diabetic patient(T2DM) and healthy control by using Arkray Adam HA-8160 HbA1c is a fully automated analyser is used for estimation that uses high performance liquid chromatography (HPLC) cation exchange method. ${ }^{12}$

\section{Results}

The study included 50 Males and 50 females were included in this study. The age range for patients and control groups was (30-65) and (29-65) years respectively as show in table(1-1). The Mean \pm Std. of glycatedhemoglobin (HbAlc \%) for patients and control. The mean for patient was highly significantly higher than that of the control group $(7.83 \pm 1.36 \%$ and $5.47 \pm 0.234 \%$ respectively) as shown in table (1-2).

Table (1): Distribution of patients and control according to Age

\begin{tabular}{|l|c|c|c|c|c|c|}
\hline \multirow{2}{*}{} & \multicolumn{2}{|c|}{ Male } & \multicolumn{2}{c|}{ Female } & \multicolumn{2}{c|}{ Total } \\
\cline { 2 - 8 } & Range & Mean \pm Std. & Range & Mean \pm Std. & Range & Mean \pm Std. \\
\hline Patients & $32-64$ & $48.28 \pm 10.17$ & $30-65$ & $40.60 \pm 9.51$ & $30-65$ & $49.40 \pm 9.461$ \\
\hline Control & $29-65$ & $39.44 \pm 9.87$ & $29-65$ & $51.28 \pm 8.86$ & $29-65$ & $40.30 \pm 8.87$ \\
\hline
\end{tabular}

Table (2): Comparison between Studied Groups according to HbA1C percent

\begin{tabular}{|l|c|c|c|c|c|}
\hline & Study Groups & Mean \pm Std. & t-test & P-Value & C.S \\
\hline \multirow{2}{*}{$\mathrm{HbA} 1 \mathrm{C} \%$} & Study & $7.83 \pm 1.36$ & 12.092 & .000 & \multirow{2}{*}{ P $<0.01(\mathrm{HS})$} \\
\cline { 2 - 5 } & Control & $5.47 \pm 0.234$ & & & \\
\hline
\end{tabular}

The result of serum leptin level summarized in the table (1-2) and figure (1-1) showed that there was highly significant difference when comparing the mean of total serum leptin of patient group $(44.48 \pm 12.41 \mathrm{ng} /$ $\mathrm{ml}$ ) with that of the control group $(38.75 \pm 7.61 \mathrm{ng} / \mathrm{ml})$. While there was no significant difference between males and females of the control group in mean serum leptin level $(36.982 \pm 6.705$ and $40.522 \pm 8.169$ respectively), 
but there was significant difference among male and female patients $(\mathrm{P}<0.05)$. And the results in table (1-3) and figure (1-2) showed the mean of total circulating resistin in T2DM patient and healthy control(10.18 \pm 3.87 and $9.71 \pm 2.02 \mathrm{ng} / \mathrm{ml}$ respectively) with no significant difference between the two groups. Furthermore, there was no significant difference between(male and female patients $(9.208 \pm 3.632$ and $11.1520 \pm 3.933 \mathrm{ng} /$ $\mathrm{ml}$ respectively). Similarly, no significant difference in circulating resistin between male and female control $(\mathrm{P}>0.05){ }^{13}$

Table (3): Comparison in Leptin level among study groups and Gender

\begin{tabular}{|c|c|c|c|c|c|c|}
\hline Leptin (ng/ml) & $\begin{array}{c}\text { Total } \\
(\text { Mean } \pm \text { Std.) } \mathrm{ng} / \mathrm{ml}\end{array}$ & $\begin{array}{c}\text { Male } \\
\text { (Mean } \pm \text { Std.) ng/ml }\end{array}$ & $\begin{array}{c}\text { Female } \\
(\text { Mean } \pm \text { Std. }) n g / m l\end{array}$ & t-test & P-Value & C.S \\
\hline Control & $38.75 \pm 7.61$ & $36.982 \pm 6.705$ & $40.522 \pm 8.169$ & 1.975 & .100 & $\mathrm{P}>0.05(\mathrm{NS})$ \\
\hline Study & $44.48 \pm 12.41$ & $40.720 \pm 12.765$ & $48.237 \pm 11.039$ & 2.227 & .031 & $\mathrm{P}<0.05$ (S) \\
\hline t-test & 2.782 & 1.296 & 2.809 & & & \\
\hline P-Value & .006 & .201 & .007 & & & \\
\hline C.S & $\mathrm{P}<0.01(\mathrm{HS})$ & $\mathrm{P}>0.05(\mathrm{NS})$ & $\mathrm{P}<0.01(\mathrm{HS})$ & & & \\
\hline
\end{tabular}

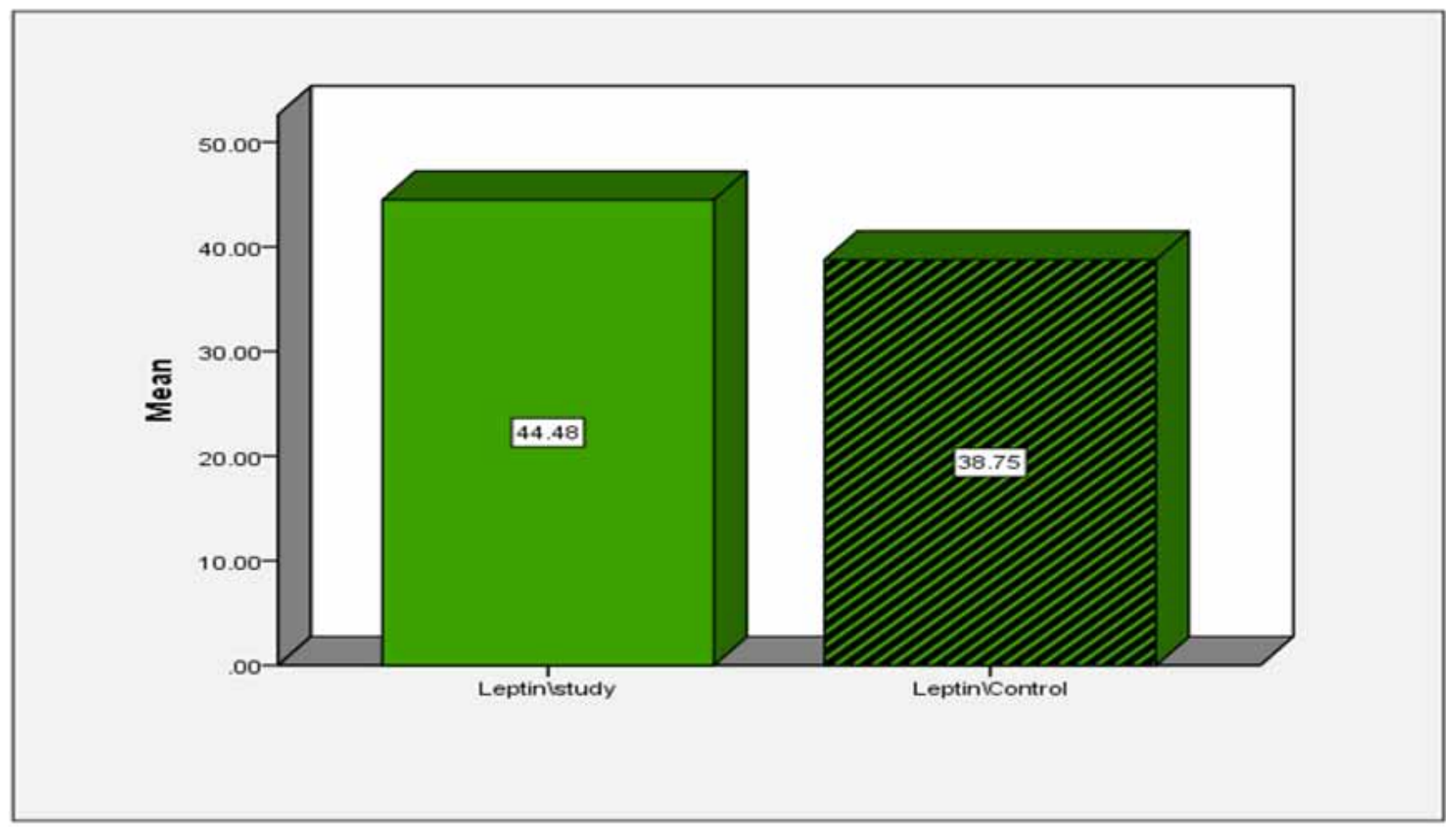

Fig. (1-1): Mean Value of Leptinamong study groups

Table (4): Comparison between studied Groups and Gender according to serum resistin

\begin{tabular}{|c|c|c|c|c|c|c|}
\hline & $\begin{array}{c}\text { Total } \\
(\text { Mean } \pm \text { Std. }) \mathrm{ng} / \mathrm{ml}\end{array}$ & $\begin{array}{c}\text { Male } \\
(\text { Mean } \pm \text { Std. }) \text { ng/ml }\end{array}$ & $\begin{array}{c}\text { Female } \\
\text { (Mean } \pm \text { Std.) ng/ml }\end{array}$ & t-test & P-Value & C.S \\
\hline Control & $9.71 \pm 2.02$ & $9.924 \pm 1.805$ & $9.504 \pm 2.236$ & 0.731 & .468 & $\mathrm{P}>0.05(\mathrm{NS})$ \\
\hline Patient & $10.18 \pm 3.87$ & $9.208 \pm 3.632$ & $11.1520 \pm 3.933$ & 1.816 & .076 & $\mathrm{P}>0.05(\mathrm{NS})$ \\
\hline t-test & 0.768 & 0.883 & 1.821 & & & \\
\hline P-Value & .446 & .203 & .075 & & & \\
\hline C.S & $\mathrm{P}>0.05(\mathrm{NS})$ & $\mathrm{P}>0.05(\mathrm{NS})$ & $\mathrm{P}>0.05(\mathrm{NS})$ & & & \\
\hline
\end{tabular}




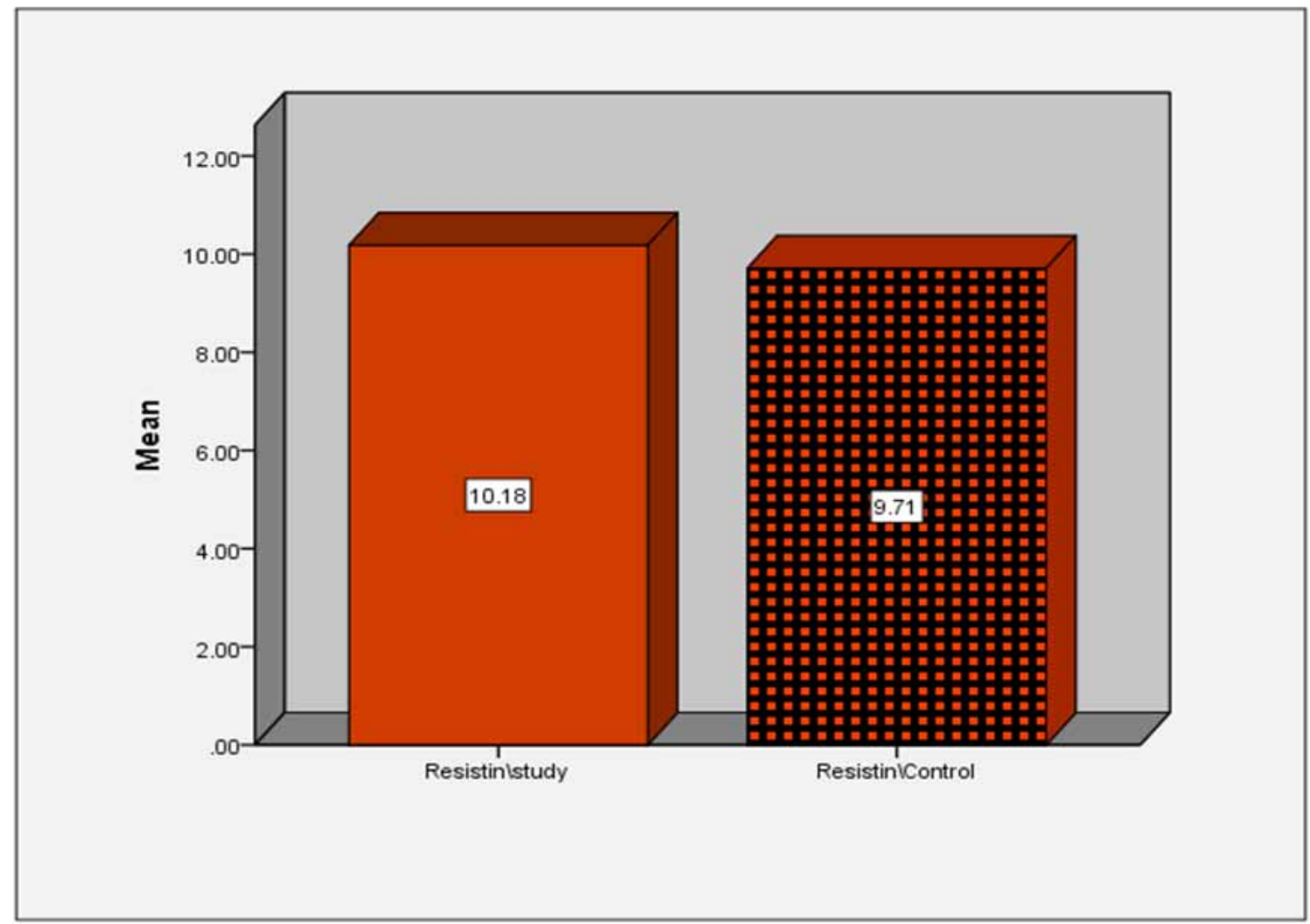

Fig. (1-2): Mean Value of Resistin among groups

\section{Discussion}

$\mathrm{HbAlc}$ analysis in the blood provides proof of the average blood glucose levels through the previous 2 to 3 months, which is estimated half-life of red blood cells (RBCs). HbA1c provides a most reliable measure of chronic glycemia and is well associated with the risk of long term complications of diabetes,so it is widely considered the test of choice for chronic diabetes management and monitoring ${ }^{14}$.

The association between leptin and diabetes mellitus in humans was examined in few studies. But Leptin is an essential hormone derived from adipose tissue which has been shown to be involved in patho-physiological processes relating to diabetes. This study is consistent with Kumar, et al., ${ }^{15}$ as the study found that the level of leptin is higher in diabetic patients compared to healthy subjects ${ }^{15}$. The human laboratory studies indicate levels of leptin are closely linked to body fatness. Serum leptin is reportedly a good biomarker of obesity. Thus, body fat can mediate an association between serum leptin and diabetes mellitus ${ }^{16}$.
Another study was agreement with these finding Gupta \& Mukherjee., who was reported that the level of serum leptin were significantly increase in diabetic patient when compared to healthy control ${ }^{17}$. In addition to that Osegbe, et al., found differences in the concentration of leptin levels, female with T2DM has higher serum leptin than healthy female and this compatible with our study ${ }^{18}$. Females with diabetes have a higher concentration of leptin compared to males, and this is consistent with Diwan, et al., study in India reported that the serum leptin levels in females were higher than in males. In addition, the serum leptin levels in diabetics were significantly higher than in nondiabetics ${ }^{19}$. On the other hand, we found that there was no difference in the level of leptin in males suffering from diabetes compared to healthy controls, and These result was compatible with Zamil.,2019 study in Iraq did not find any significant association in leptin concentration between male with T2DM and healthy control ${ }^{20}$.

In present study there was no signficant difference between type 2 diabetic patient and control . This study is in agreement with Zamil .2019 a study in Baghdad that 
concluded that there is no difference in the concentration of risistin in patients with type 2 diabetes and among healthy subjects ${ }^{20}$. The main biological effects of resistin are associated with increased blood glucose levels and obesity in some animal models, explained in part as a result of increased production of hepatic glucose $\mathrm{e}^{21}$. Resistin is an adipokine that acts as a biomarker for inflammation and a mediator of insulin resistance linked to obesity ${ }^{22}$. Resistin in humans reduce insulin-stimulated glucose in the isolated adipocytes. The fundamental mechanisms these effects remain unclear while data aim to suppress resistin AMPK activity, primarily in the liver, due to cytokine stimulation-3 suppressor activation $^{23}$. These results are also in agreement with Pfützner, et al., No significant association was found between serum resistin levels and obesity and insulin resistant clinical measures ${ }^{24}$. Bu et al .also found resistin levels in both the T2DM and the normoglycemic group had no relationship to insulin resistance ${ }^{25}$.

Financial Disclosure: There is no financial disclosure.

Conflict of Interest: None to declare.

Ethical Clearance: All experimental protocols were approved under the National Blood Transfusion Center and all experiments were carried out in accordance with approved guidelines.

\section{References}

1. Cefalu WT, Berg EG, Saraco M, Petersen MP, Uelmen S, Robinson S. Classification and diagnosis of diabetes: standards of medical care in diabetes-2019. Diabetes Care. 2019 Jan 1;42:S1328.

2. Röder PV, Wu B, Liu Y, Han W. Pancreatic regulation of glucose homeostasis. Experimental \& molecular medicine. 2016 Mar;48(3):e219-.

3. Doddigarla Z, Parwez I, Ahmad J. Correlation of serum chromium, zinc, magnesium and SOD levels with $\mathrm{HbA1c}$ in type 2 diabetes: a cross sectional analysis. Diabetes \& Metabolic Syndrome: Clinical Research \& Reviews. 2016 Jan 1;10(1):S126-9.

4. Dasari R, Raghunath V. Obesity and Type II diabetes mellitus: Is resistin the link? Journal of Diabetes and Endocrine Practice. 2018 Oct 1;1(1):1.

5. Williams KW, Scott MM, Elmquist JK. From observation to experimentation: leptin action in the mediobasal hypothalamus. The American journal of clinical nutrition. 2009 Mar 1;89(3):985S-90S.

6. Zhang Y, Proenca R, Maffei M, Barone M, Leopold L, Friedman JM. Positional cloning of the mouse obese gene and its human homologue (1994) Nature, 372 (6505). DOI.;10:425-32.

7. Ahima RS, Flier JS. Leptin. Annual review of physiology. 2000 Mar;62(1):413-37.

8. Zinman B, Lachin JM, Inzucchi SE. Empagliflozin, cardiovascular outcomes, and mortality in type 2 diabetes. The New England journal of medicine. 2016 Mar 17;374(11):1094.

9. Patel L, Buckels AC, Kinghorn IJ, Murdock PR, Holbrook JD, Plumpton C, Macphee CH, Smith SA. Resistin is expressed in human macrophages and directly regulated by $\operatorname{PPAR} \gamma$ activators. Biochemical and biophysical research communications. 2003 Jan 10;300(2):472-6.

10. Lau, C. H., \& Muniandy, S. (2011). Adiponectin and resistin gene polymorphisms in association with their respective adipokine levels. Annals of human genetics, 75(3), 370-382.

11. Fontana A, Moreno LO, Lamacchia O, De Bonis C, Salvemini L, De Cosmo S, Cignarelli M, Copetti M, Trischitta V, Menzaghi C. Serum resistin is causally related to mortality risk in patients with type 2 diabetes: preliminary evidences from genetic data. Scientific reports. 2017 Mar 3;7(1):1-6.

12. Thevarajah TM, Nani N, Chew YY. Performance evaluation of the Arkray Adams HA-8160 HbA 1c analyser. Malaysian Journal of Pathology. 2008 Dec 1;30(2).

13. Ahmed Sa'adiHassanAnti malignant (HepG2, MOLT-3) Activity of One, Two, BaghdadIndian Journal of Forensic Medicine \& Toxicology 2020 April-June14 . 2.1411-1418

14. Sherwani SI, Khan HA, Ekhzaimy A, Masood A, Sakharkar MK. Significance of HbAlc test in diagnosis and prognosis of diabetic patients. Biomarker insights. 2016 Jan;11:BMI-S38440.

15. Kumar A, Chopra S, Lal AK. Serum leptin and body mass index in type 2 diabetes mellitus patients of Dehradun, Uttarakhand, India. Int. J. Curr. Microbiol. App. Sci. 2015;4(12):434-40.

16. Kanaya AM, Fyr CW, Vittinghoff E, Harris TB, Park SW, Goodpaster BH, Tylavsky F, Cummings SR. Adipocytokines and incident diabetes mellitus in older adults: the independent effect of plasminogen activator inhibitor 1. Archives of 
Internal Medicine. 2006 Feb 13;166(3):350-6.

17. Gupta M, Mukherjee R. Study on "A Comparative Study of Serum Leptin and Lipid Profile among Non-Diabetic Obese Subjects and Type 2 Diabetic Patients due to Obesity". BiochemInd J. 2018;12(3):132.

18. Osegbe I, Okpara H, Azinge E. Relationship between serum leptin and insulin resistance among obese Nigerian women. Annals of African medicine. 2016 Jan;15(1):14.

19. Diwan AG, Kuvalekar AA, Dharamsi S, Vora AM, Nikam VA, Ghadge AA. Correlation of serum adiponectin and leptin levels in obesity and type 2 diabetes mellitus. Indian journal of endocrinology and metabolism. $2018 \mathrm{Jan} ; 22(1): 93$.

20. Zamil, G .O (2019) Serum Concentration of Irisin, Resistin, Leptin and 25-Hydroxyvitamin D in Iraqi Men with Type 2 Diabetes Mellitus: Obesityrelated study. [Doctoral dissertation, University of Baghdad/collage of medicin].

21. Park HK, Ahima RS. Resistin in rodents and humans. Diabetes \& metabolism journal. 2013 Dec 1;37(6):404-14.
22. Codoñer-Franch P, Alonso-Iglesias E. Resistin: insulin resistance to malignancy. Clinicachimicaacta. 2015 Jan 1;438:46-54.

23. Rajkovic N, Zamaklar M, Lalic K, Jotic A, Lukic L, Milicic T, Singh S, Stosic L, Lalic NM. Relationship between obesity, adipocytokines and inflammatory markers in type 2 diabetes: relevance for cardiovascular risk prevention. International journal of environmental research and public health. 2014 Apr;11(4):4049-65.

24. Pfützner A, Langenfeld M, Kunt T, Löbig M, Forst T. Evaluation of human resistin assays with serum from patients with type 2 diabetes and different degrees of insulin resistance. Clinical laboratory. 2003;49(11-12):571.

25. Bu J, Feng Q, Ran J, Li Q, Mei G, Zhang Y. Visceral fat mass is always, but adipokines (adiponectin and resistin) are diversely associated with insulin resistance in Chinese type 2 diabetic and normoglycemic subjects. Diabetes Research and Clinical Practice. 2012;96(2):163-9. 